\title{
Balancing the benefits and risks of public-private partnerships to address the global double burden of malnutrition
}

\author{
Vivica I Kraak ${ }^{1, *}$, Paige B Harrigan ${ }^{2}$, Mark Lawrence ${ }^{3}$, Paul J Harrison ${ }^{4}$, \\ Michaela A Jackson ${ }^{5}$ and Boyd Swinburn ${ }^{6}$ \\ 'WHO Collaborating Centre for Obesity Prevention, and Deakin Population Health Strategic Research Centre, \\ School of Health and Social Development, Deakin University, 221 Burwood Highway, Burwood, Victoria 3125, \\ Australia: ${ }^{2}$ Nutrition, Health and Food Security, Save the Children, Washington, DC, USA: ${ }^{3}$ Public Health \\ Nutrition, WHO Collaborating Centre for Obesity Prevention, Deakin Population Health Strategic Research \\ Centre, School of Exercise and Nutrition Sciences, Deakin University, Burwood, Victoria, Australia: ${ }^{4}$ Deakin \\ Graduate School of Business, Deakin University, Burwood, Victoria, Australia: ${ }^{5}$ Population Health Strategic \\ Research Centre, School of Health and Social Development, Deakin University, Burwood, Victoria, Australia: \\ ${ }^{6}$ WHO Collaborating Centre for Obesity Prevention, Deakin Population Health Strategic Research Centre, \\ Deakin University, Burwood, Victoria, Australia
}

Submitted 23 November 2010: Accepted 8 July 2011: First published online 13 October 2011

\begin{abstract}
Objective: Transnational food, beverage and restaurant companies, and their corporate foundations, may be potential collaborators to help address complex public health nutrition challenges. While UN system guidelines are available for private-sector engagement, non-governmental organizations (NGO) have limited guidelines to navigate diverse opportunities and challenges presented by partnering with these companies through public-private partnerships (PPP) to address the global double burden of malnutrition.

Design: We conducted a search of electronic databases, UN system websites and grey literature to identify resources about partnerships used to address the global double burden of malnutrition. A narrative summary provides a synthesis of the interdisciplinary literature identified.

Results: We describe partnership opportunities, benefits and challenges; and tools and approaches to help NGO engage with the private sector to address global public health nutrition challenges. PPP benefits include: raising the visibility of nutrition and health on policy agendas; mobilizing funds and advocating for research; strengthening food-system processes and delivery systems; facilitating technology transfer; and expanding access to medications, vaccines, healthy food and beverage products, and nutrition assistance during humanitarian crises. PPP challenges include: balancing private commercial interests with public health interests; managing conflicts of interest; ensuring that co-branded activities support healthy products and healthy eating environments; complying with ethical codes of conduct; assessing partnership compatibility; and evaluating partnership outcomes. Conclusions: NGO should adopt a systematic and transparent approach using available tools and processes to maximize benefits and minimize risks of partnering with transnational food, beverage and restaurant companies to effectively target the global double burden of malnutrition.
\end{abstract}

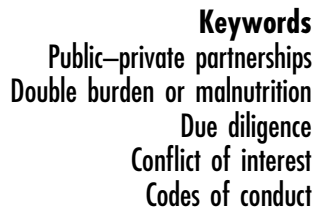

Transformative systems change is needed to resolve global public health nutrition challenges ${ }^{(1)}$ including the double burden of malnutrition - a worldwide phenomenon representing the coexistence of maternal and child undernutrition (i.e. wasting, stunting and underweight) and micronutrient deficiencies (i.e. iron, vitamin A, iodine and zinc) with child or adult overweight, obesity and noncommunicable diseases (NCD) in affected households, communities or populations ${ }^{(2-6)}$.
An estimated 925 million people worldwide are hungry or malnourished ${ }^{(7)}$. Child undernutrition and micronutrient deficiencies cause approximately 8 million deaths in children under 5 years of age, contribute to child and adult morbidity ${ }^{(8,9)}$, and prevent more than 200 million young children from reaching their full developmental potential $^{(10)}$. At the other end of the global malnutrition spectrum, about 43 million pre-school children under 5 years ${ }^{(11)}$ and approximately 155 to 200 million school-aged 
children $^{(12)}$ worldwide are overweight or obese. In 2008, an estimated 1.46 billion men and women worldwide were overweight and more than half a billion adults were obese $^{(13)}$. Two-thirds of the 57 million global deaths were attributed to lifestyle-related NCD, of which $80 \%$ were in low- and middle-income countries ${ }^{(14,15)}$.

The double burden of malnutrition will place tremendous pressure on resource-constrained health systems ${ }^{(14,15)}$. An estimated \$US 10-12 billion annually is required to scale up thirteen proven nutrition interventions in thirty-six countries to prevent and treat undernutrition ${ }^{(16)}$ and \$US 9 billion annually to implement five priority actions to reduce NCD risks globally ${ }^{(14)}$.

\section{Partnerships addressing global nutrition challenges}

Developing transformative systems change to tackle these global nutrition challenges will require new stakeholder engagement approaches and governance structures that support public- and private-sector participation ${ }^{(1,17)}$. UN system organizations ${ }^{(7,16,18-20)}$ and public health experts ${ }^{(21,22)}$ have encouraged governments, non-governmental organizations (NGO) ${ }^{(23)}$ and civil society organizations ${ }^{(24) *}$ to collaborate with the private sector using public-private partnerships (PPP) to address complex public health challenges (Table 1).

The WHO defines a PPP as a collaboration between public- and private-sector actors within diverse arrangements that vary according to participants, legal status, governance, management, policy setting, contributions and operational roles to achieve specific outcomes ${ }^{(25)}$. Many PPP are social alliances designed to achieve common goals benefiting society and all partners ${ }^{(26,27)}$. Partnership relationships are defined by engagement level, strategic value of the alliance to each partner's mission, resource investments and managerial complexity ${ }^{(26)}$.

PPP take place within a context of governments being publicly accountable for protecting and promoting the nutritional health of populations. Since the 1980s, governments have increasingly relied on market-driven solutions to address public health nutrition challenges. This trend has been reinforced by WHO in policy documents emphasizing private-sector engagement through partnerships to change the upstream determinants of health ${ }^{(28,29)}$.

Several UN system organizations ${ }^{(7,30,31)}$ identify global food and beverage companies as important stakeholders to help promote a healthful diet and achieve the human right to food security. It has been suggested that transnational food, beverage and restaurant companies, and

\footnotetext{
* The terms NGO and CSO (civil society organization) are often used interchangeably to represent legally constituted entities that are independent from government and the private sector, representing registered charities, community groups, faith-based organizations, professional associations, industry or business groups, trade unions, coalitions or advocacy groups. Table 1 defines of key terms.
}

their corporate foundations, may be potential collaborators to address global hunger and food insecurity ${ }^{(32)}$, infant and early childhood undernutrition and micronutrient deficiencies ${ }^{(10,33,34)}$, and obesity and $\operatorname{NCD}^{(27,35)}$.

NGO are important stakeholders to advocate for and implement direct-service programmes reaching disadvantaged populations and protect public health interests by monitoring government and industry actions ${ }^{(24)}$. However, NGO partnerships with global companies have encountered controversy over discordant values, questionable motives, inadequate management of conflicts of interest, endorsement of branded products and marketing strategies, perceived co-option of public health goals by commercial interests, lack of distinction between publicand business-interest NGO, and weak safeguards to protect public health interests ${ }^{(29,36-42)}$. NGO partnerships with companies have attracted negative attention that diminishes public trust for an NGO's brand ${ }^{(43,44)}$. While UN system guidelines are available for private-sector engagement $^{(18,45,46)}$, NGO have limited guidelines to navigate and proactively manage the diverse opportunities and challenges presented by partnering with these companies.

In the present paper we describe PPP used to address the global double burden of malnutrition; explore special opportunities and challenges of NGO partnering with transnational food, beverage and restaurant companies; and discuss approaches to help NGO balance the benefits and risks of PPP to effectively target the global double burden of malnutrition.

\section{Methods}

We conducted a search of electronic databases (i.e. Academic Search Complete, Health Source and MEDLINE), UN system organization websites and grey literature to identify resources about partnerships and alliances used to address components of the double burden of malnutrition. The authors were also referred to relevant articles and reports by colleagues. We use a narrative summary to present the synthesized evidence acquired from the interdisciplinary literature representing business, public health, nutrition sciences, public policy, risk analysis and ethical perspectives.

\section{Results}

PPP are used to tackle health inequalities, alleviate poverty and promote social innovation for health ${ }^{(47,48)}$; expand services for HIV/AIDS, tuberculosis and malaria ${ }^{(49)}$; distribute vaccines and medications ${ }^{(50)}$; mitigate global hunger and food insecurity ${ }^{(32,51,52)}$; and strengthen community disaster response ${ }^{(53)}$. Partnerships are also used to target the causal links and leverage points for life-cycle susceptibilities associated with the global double burden of malnutrition (Fig. 1) $)^{(5)}$, including 
Table 1 Key terms defined (adapted from references 2-5, 17, 23-25, 27, 59, 62, 70-72, 85, 92, 93, 101-105 and 132)

Term Definition

Accountability

Bias

Cause marketing

Civil society

Collaboration

Conflict of interest

Contributions in-kind Double burden of malnutrition

Non-governmental organization (NGO)

Partnership

Public-private partnership

Sponsorship

Transparency
A concept linked to institutional performance which encompasses the factors that influence decision making. Accountability has two main components: (i) answerability, which involves key actors providing an account of their decision and actions to relevant stakeholders using a trusted, transparent, responsive, credible and inclusive process that provides meaningful and verifiable information; and (ii) enforceability, which involves key actors complying with established standards, codes of conduct, and receiving penalties or restrictions when they do not deliver on their pledges, commitments and obligations $^{(132)}$

Any process that fosters prejudice favouring a particular person or viewpoint, or that results in deviations in how data are reviewed or analysed, interpreted or published to produce conclusions that are inconsistent with the truth ${ }^{(103)}$. A 'white hat bias' is the tendency to distort the truth and disregard the facts when the distortions are perceived to serve righteous ends ${ }^{(105)}$

A joint commercial and promotional campaign in which a company's sales are linked and a percentage of the sales revenue is given to a charity or other public cause. Cause marketing benefits both the company and NGO when consumers purchase the company's branded products or services, and may include merchandise licenses and co-branded sponsorships ${ }^{(72)}$

A term that refers to the shared interests and collective actions of voluntary civic and social organizations and institutions that form the basis of a functioning society. Civil society is distinct from the public sector (government) and the private sector (commercial enterprises). Examples of civil society organizations (CSO) include social movements, voluntary organizations, NGO, grassroots organizations and other non-profit stakeholders ${ }^{(24)}$

Comprises activities that enhance the capacity of partners to produce mutual benefit and work towards a common purpose ${ }^{(62)}$

Arises when an individual's or organization's ability to exercise judgement in one role is influenced by obligations in another role or by competing interest. For example, a person or organization may put aside primary interests (such as advocacy for public health) in favour of a secondary set of interests (such as the financial well-being of a commercial entity or receiving a financial benefit) ${ }^{(92,101-104)}$

A non-monetary donation of a branded product or service made by a company to an $\mathrm{NGO}^{(59,72)}$

The coexistence in a household, community or population of child and maternal undernutrition (i.e. wasting, stunting and underweight) and micronutrient deficiencies (i.e. iron, vitamin A, iodine and zinc) with child or adult overweight, obesity and lifestyle-related chronic diseases ${ }^{(2-5)}$

Any local, national or international non-profit group that is task-oriented, driven by people with a common interest, and that performs a variety of service and humanitarian functions such as conducting analyses and sharing expertise, serving as an early warning mechanism, or helping to monitor and implement international agreements ${ }^{(23,24)}$. Some make clear distinctions between public-interest NGO (PINGO), such as consumer or public health advocacy organizations, and business-interest NGO (BINGO), such as industry trade associations

A mechanism for bringing together a diversity of skills and resources of various organizations in innovative ways to improve specific outcomes ${ }^{(25,62)}$

A collaboration between public- and private-sector actors within diverse arrangements that vary according to participants, legal status, governance, management, policy setting, contributions and operational roles to achieve specific outcomes ${ }^{(25)}$

Any form of monetary or in-kind payment or contribution to an event, activity or individual that directly or indirectly promotes a company's name, brand, products or services. Sponsorship is a commercial transaction, not a philanthropic gift $^{70,71)}$

To create processes that foster openness, disclosure of information and clear communication to support accountability. Examples of transparent procedures include public meetings, financial disclosure statements, audits, freedom of information legislation, annual reports and budgetary review ${ }^{(132)}$ undernutrition and micronutrient deficiencies targeted by the UN Millennium Development Goals (MDG) ${ }^{(20,49,54-57)}$; overweight and obesity targeted by WHO's Global Strategy on Diet, Physical Activity and Health ${ }^{(31)}$; and chronic diseases targeted by WHO's Global Strategy to Prevent and Control Noncommunicable Diseases ${ }^{(58)}$.

Evaluations of PPP benefits suggest they can raise the visibility of nutrition and health on policy agendas; mobilize funds and advocate for research; strengthen health-policy and food-system processes and delivery systems; facilitate technology transfer; establish treatment protocol standards; expand target populations' access to free or reduced-cost medications, vaccines, healthy food and beverage products; and distribute 'essential packages' of nutrition assistance during humanitarian crises ${ }^{(50,59-61)}$.

\section{Features of effective partnerships}

Donors, governments, transnational companies, corporate and private foundations, NGO and academic institutions can address global malnutrition through diverse interactions, institutional commitments, joint research efforts and multisectoral programmes. PPP imply mutuality and equality between partners. Partnerships can be described on a continuum ranging from networking to coordination, cooperation and collaboration ${ }^{(62)}$. Austin $^{(26)}$ describes three types of partnerships - philanthropic, transactional and transformative, discussed below and in Tables 2 and 3.

Partnerships may generate tension among the institutional cultures of government, industry and NGO and involve risk taking to produce meaningful change at scale $^{(63)}$. Private-sector partners are often independent of 


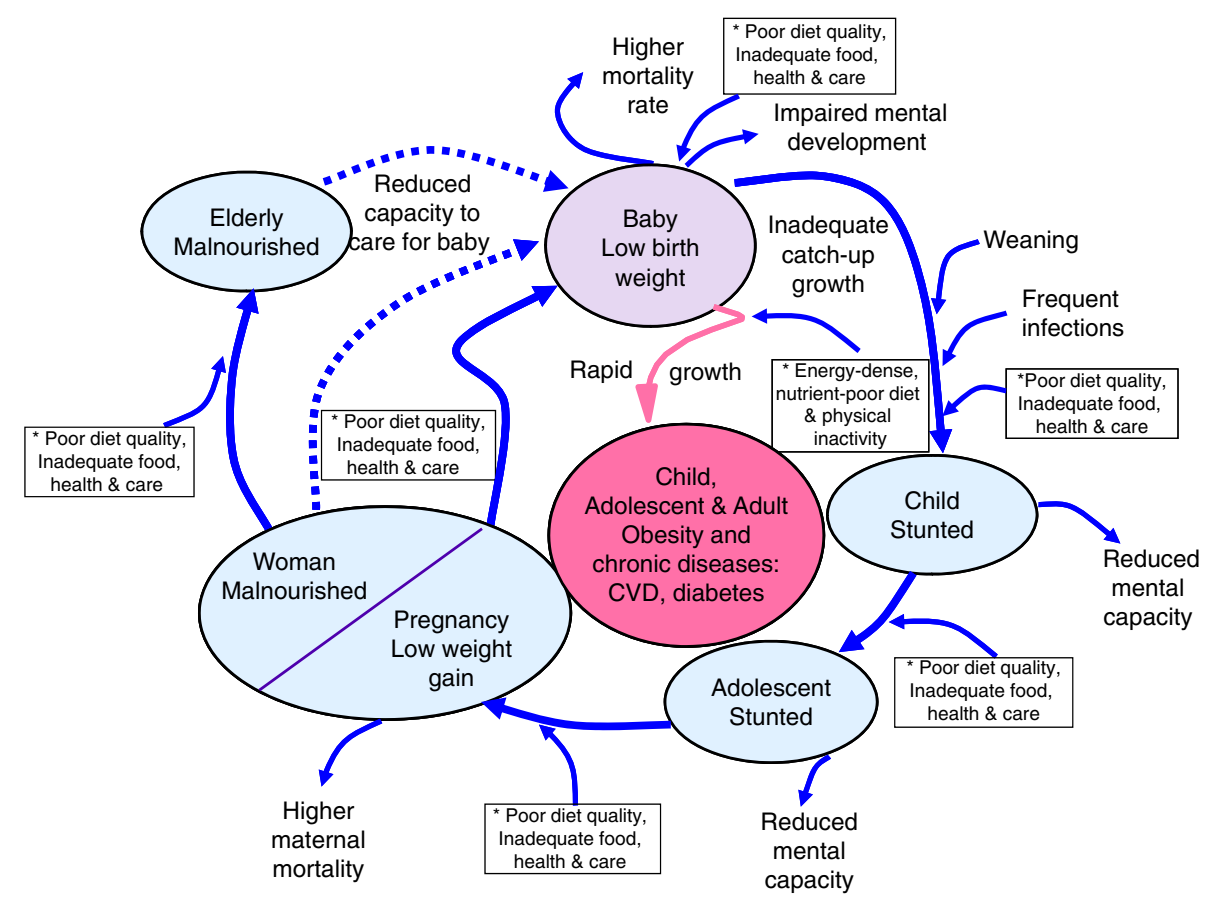

Fig. 1 (colour online) Proposed causal links and leverage points* for public-private partnerships to address life-cycle susceptibilities linked to the global double burden of malnutrition (adapted from James et al. $(2005)^{(5)}$ )

the political mandates of national, state or local governments and they may mobilize more specific expertise and greater capital more efficiently and cost-effectively than public-sector partners. However, private-sector solutions are driven by commercial imperatives to generate profits, can produce inequities and may not reach vulnerable groups. Indeed, corporations have no intrinsic motivation to address existing health or social inequities that are priorities for governments and civil society. These are important tensions to acknowledge when considering a PPP approach.

Effective partnerships develop trusting relationships to share information, technology and promote innovation; leverage financial or in-kind resources, expertise, influence, networks and distribution systems; and manage legitimacy and the collaborative structure to ensure that organizational assets are aligned with common missions, goals and objectives to reach populations with larger-scale activities than each partner can deliver on its own ${ }^{(26,27,53,64-67)}$.

\section{Philanthropic partnerships}

Philanthropic partnerships involve limited engagement, reciprocity and activities that are peripherally important to each partner's mission. A philanthropic partnership occurs when a company gives a charitable financial or food donation to an NGO either through an anonymous or acknowledged donation accompanied by media coverage for each partner ${ }^{(51,59,68,69)}$.

\section{Transactional partnerships}

Transactional partnerships build mutually beneficial relationships to advance each partner's agenda through compatibility among organizational values, missions and goals ${ }^{(26)}$. These partnerships involve higher levels of interaction and resource investments compared with philanthropic partnerships. Table 1 defines terms (i.e. contributions-in-kind, co-branded sponsorships and cause marketing) ${ }^{(70-72)}$ that are revenue-raising instruments used by NGO to implement programmes. While transactional partnerships may enhance a company's brand reputation, they can adversely affect an NGO's reputation ${ }^{(43,44,59)}$. Examples of transactional partnerships $^{(39,73-82)}$ are provided in Tables 2 and 3.

\section{Transformational partnerships}

Transformational partnerships involve the highest level of engagement, resource investment, managerial complexity and relationships built over time to mutually influence the institutional cultures and practices of each partner. Transformational partnerships involve many partners to stimulate large-scale social or policy changes ${ }^{(1)}$ to address the double burden of malnutrition (Fig. 1). Examples of aspiring transformational partnerships ${ }^{(54-56,83,84)}$ are discussed below and in Tables 2 and 3. Thereafter, we present certain conceptual, practical and ethical challenges.

\section{Maternal and child bealth integrated programmes to address undernutrition \\ In 2008, the US government funded the Maternal Child Health Integrated Program (MCHIP) to accelerate pro- gress towards MDG 4 (reduce infant and child mortality) and MDG 5 (improve maternal health) in thirty priority countries $^{(57)}$. MCHIP uses partnerships with governments}


Table 2 Examples of public-private partnerships that address global nutrition challenges (adapted from references 26, 54, 55, 59, 68-69, 73-82 and 85)

\begin{tabular}{|c|c|c|c|}
\hline & Philanthropic & Transactional & Transformational \\
\hline $\begin{array}{l}\text { Nature of the relationship } \\
\text { Level of engagement } \\
\text { Importance to each partner's mission } \\
\text { Resource investment } \\
\text { Scope of activities } \\
\text { Level of interaction } \\
\text { Managerial complexity } \\
\text { Strategic value to each partner }\end{array}$ & $\begin{array}{l}\text { Low } \\
\text { Peripheral } \\
\text { Small } \\
\text { Narrow } \\
\text { Infrequent } \\
\text { Simple } \\
\text { Minor }\end{array}$ & $\begin{array}{l}\text { Medium } \\
\text { More important } \\
\text { Medium } \\
\text { Focused } \\
\text { Moderate } \\
\text { Moderate } \\
\text { More salient }\end{array}$ & $\begin{array}{l}\text { High } \\
\text { Central } \\
\text { Substantial } \\
\text { Broad } \\
\text { Intensive } \\
\text { Highly complex } \\
\text { High }\end{array}$ \\
\hline Types of partnership & $\begin{array}{l}\text { Charitable financial donations } \\
\text { that enhance each partner's } \\
\text { brand image }\end{array}$ & $\begin{array}{l}\text { Co-branded sponsorships } \\
\text { Gifts-in-kind } \\
\text { Cause marketing } \\
\text { Contractual services }\end{array}$ & $\begin{array}{l}\text { Joint, multi-institutional research initiatives } \\
\text { Large-scale national or global food-fortification } \\
\text { programmes } \\
\text { Large-scale humanitarian relief and emergency } \\
\text { nutrition programmes in response to natural } \\
\text { disasters and civic conflicts } \\
\text { Healthy-lifestyles programmes to prevent obesity }\end{array}$ \\
\hline Examples & $\begin{array}{l}\text { Yum! Brands Inc. and Burger King } \\
\text { donate funding or food to NGO to } \\
\text { implement programmes that } \\
\text { address domestic or global } \\
\text { hunger and emergency relief }\end{array}$ & $\begin{array}{l}\text { PepsiCo and Kraft Foods partner with Save the } \\
\text { Children to address child malnutrition in Asia } \\
\text { PepsiCo partners with the WFP and The Coca- } \\
\text { Cola Company partners with the International } \\
\text { Federation of the Red Cross and Red Crescent } \\
\text { Societies to support disaster response and } \\
\text { preparedness for global humanitarian relief } \\
\text { Yum! Brands Inc. partners with the WFP to provide } \\
\text { food to people affected by disasters through the } \\
\text { company's annual World Hunger Relief Campaign } \\
\text { McDonald's Corporation sponsors Ronald } \\
\text { McDonald houses for parents of children who } \\
\text { are hospitalized } \\
\text { Food, beverage and restaurant companies } \\
\text { sponsor athletic events including the Olympics } \\
\text { and the World Cup } \\
\text { Cadbury partnered with UNICEF Canada to sell } \\
\text { co-branded chocolate and candy to raise funds } \\
\text { supporting children's education in Africa }\end{array}$ & $\begin{array}{l}\text { MCHIP partners with governments and NGO (i.e. Jhpiego, } \\
\text { Save the Children and John Snow International) to } \\
\text { promote integrated maternal, infant and young child } \\
\text { nutrition in } 30 \text { priority countries } \\
\text { GAIN partners with NGO, governments and many food } \\
\text { and beverage companies to address micronutrient } \\
\text { deficiencies through national and global food- } \\
\text { fortification programmes in } 25 \text { countries } \\
\text { Multi-sectoral government agencies, NGO and several } \\
\text { companies partner to implement specific humanitarian- } \\
\text { relief programmes that address the nutrition needs of } \\
\text { malnourished populations resulting from conflicts and } \\
\text { natural disasters (i.e. Indonesian tsunami and Haitian } \\
\text { earthquake) } \\
\text { Ten food and beverage companies partner with } \\
\text { NGOs to support global healthy-lifestyles programmes } \\
\text { to prevent obesity and NCD through the IFBA } \\
\text { The HWCF is a US industry coalition of } 170 \text { food, } \\
\text { beverage and food retailer companies that partners with } \\
\text { BINGO (i.e. industry trade associations), PINGO } \\
\text { (i.e. direct service and health promotion organizations), } \\
\text { private foundations (i.e. Partnership for a Healthier } \\
\text { America) and the federal government (Let's Move!) } \\
\text { to implement healthy-lifestyle interventions and } \\
\text { programmes in the marketplace, at worksites and } \\
\text { schools to prevent obesity by promoting energy } \\
\text { balance and a healthy weight }\end{array}$ \\
\hline
\end{tabular}

NGO, non-governmental organization; WFP, World Food Programme; MCHIP, Maternal Child Health Integrated Program; GAIN, Global Alliance for Improved Nutrition; NCD, non-communicable diseases; IFBA, International Food \& Beverage Alliance; HWCF, Healthy Weight Commitment Foundation; BINGO, business-interest non-governmental organization; PINGO, public-interest non-governmental organization. 
Table 3 Profiles of transnational food, beverage and restaurant companies that use public-private partnerships to address global nutrition challenges (adapted from references $56,83-84,87$, $89,90,134-148)$

\begin{tabular}{|c|c|c|c|c|c|c|c|}
\hline Company (source) & $\begin{array}{c}\text { Headquarters (city, US } \\
\text { state/country) }\end{array}$ & $\begin{array}{l}\text { Estimated annual } \\
\text { revenue* in \$US }^{*} \text { billions (year) }\end{array}$ & $\begin{array}{l}\text { No. of countries } \\
\text { where company } \\
\text { supports } \\
\text { commercial } \\
\text { enterprises }\end{array}$ & $\begin{array}{l}\text { Supports hunger } \\
\text { alleviation, food security or } \\
\text { microenterprise initiatives } \\
\text { or new business } \\
\text { development }\end{array}$ & $\begin{array}{l}\text { GAIN Business } \\
\text { Alliance } \\
\text { member } \\
(56,87)\end{array}$ & $\begin{array}{c}\text { IFBA } \\
\text { member }^{(83,89)}\end{array}$ & $\begin{array}{c}\mathrm{HWCF} \\
\text { member }^{(84,89)}\end{array}$ \\
\hline Burger King (2009) ${ }^{(134)}$ & Miami, Florida & $2 \cdot 5(2009)$ & 74 & $\mathrm{Y}$ & $\mathrm{N}$ & $\mathrm{N}$ & $\mathrm{N}$ \\
\hline Cargill $(2010)^{(135)}$ & Minnetonka, Minnesota & $108(2010)$ & 66 & $\mathrm{Y}$ & Y & $\mathrm{N}$ & $\mathrm{N}$ \\
\hline Danone $(2009)^{(136)}$ & Paris, France & $21.5(2009)$ & 72 & $\mathrm{Y}$ & $\mathrm{Y}$ & $\mathrm{N}$ & $\mathrm{N}$ \\
\hline General Mills (2011) ${ }^{(137)}$ & Minneapolis, Minnesota & $16(2010)$ & 100 & Y & $\mathrm{N}$ & $\mathrm{Y}$ & $Y$ \\
\hline Heinz $(2009)^{(138)}$ & Pittsburgh, Pennsylvania & $10(2009)$ & 50 & Y & $\mathrm{N}$ & $\mathrm{N}$ & $\mathrm{N}$ \\
\hline $\begin{array}{l}\text { Kellogg Company } \\
(2009)^{(139)}\end{array}$ & Battle Creek, Michigan & $13(2009)$ & 180 & Y & $\mathrm{N}$ & $\mathrm{Y}$ & $\mathrm{Y}$ \\
\hline Kraft Foods $(2010)^{(140)}$ & Northfield, Illinois & $48(2010)$ & 160 & $\mathrm{Y}$ & $\mathrm{Y}$ & $\mathrm{Y}$ & $\mathrm{Y}$ \\
\hline Mars Inc. $(2008)^{(141)}$ & McLean, Virginia & $30(2008)$ & 56 & $\mathrm{Y}$ & $\mathrm{Y}$ & $\mathrm{Y}$ & $\mathrm{Y}$ \\
\hline $\begin{array}{l}\text { McDonald's Corporation } \\
(2010)^{(142,143)}\end{array}$ & Oak Brook, Illinois & $24(2010)$ & 100 & $\mathrm{~N}$ & $\mathrm{~N}$ & $\mathrm{~N}$ & $\mathrm{~N}$ \\
\hline Nestle S.A. (2009) ${ }^{(144)}$ & Vevey, Switzerland & $111(2009)$ & 86 & $\mathrm{Y}$ & $\mathrm{N}$ & $\mathrm{Y}$ & $\mathrm{Y}$ \\
\hline PepsiCo $(2010)^{(145)}$ & Purchase, New York & $43(2009)$ & 200 & Y & $Y$ & $Y$ & $\mathrm{Y}$ \\
\hline $\begin{array}{l}\text { The Coca-Cola Company } \\
(2010)^{(146)}\end{array}$ & Atlanta, Georgia & $32(2009)$ & 200 & $\mathrm{Y}$ & $\mathrm{Y}$ & $\mathrm{Y}$ & $\mathrm{Y}$ \\
\hline $\begin{array}{l}\text { The Hershey Company } \\
(2009)^{(147)}\end{array}$ & Hershey, Pennsylvania & 5 (2009) & 50 & $\mathrm{Y}$ & $\mathrm{N}$ & $\mathrm{N}$ & $\mathrm{Y}$ \\
\hline Unilever $(2010)^{(148)}$ & $\begin{array}{l}\text { Rotterdam, Netherlands } \\
\text { and London, UK }\end{array}$ & $53 \cdot 9(2009)$ & 170 & $\mathrm{Y}$ & $\mathrm{Y}$ & $\mathrm{Y}$ & $\mathrm{Y}$ \\
\hline Yum! Brands (2009) ${ }^{(149)}$ & Louisville, Kentucky & $10 \cdot 8(2009)$ & 110 & $\mathrm{Y}$ & $\mathrm{N}$ & $\mathrm{N}$ & $\mathrm{N}$ \\
\hline
\end{tabular}

GAIN, Global Alliance for Improved Nutrition; IFBA, International Food \& Beverage Alliance; HWCF, Healthy Weight Commitment Foundation.

*Estimated annual revenue represents income that a company receives from its normal business activities from the sale of goods and services to customers. Revenue figures are derived from each company's annual or corporate social responsibility report and/or website. 
and NGO to implement programmes at scale to improve maternal and child nutrition and health ${ }^{(57,85)}$. In 2011, a global PPP, Saving Lives at Birth, was launched by the US government, private funders, Grand Challenges Canada and the World Bank ${ }^{(86)}$

Evaluations of child survival programmes suggest that countries achieve the greatest impact by developing strategic PPP supporting mutual programme objectives; responding to each country's specific cultural factors; leveraging each partner's technical expertise and resources to meet clear objectives; and implementing highimpact interventions through scaled-up programmes for broad population coverage ${ }^{(57)}$.

\section{Global Alliance for Improved Nutrition to address micronutrient deficiencies}

Global Alliance for Improved Nutrition (GAIN) is an international alliance that addresses poor health and malnutrition among vulnerable groups by improving their diet quality ${ }^{(55,56)}$. GAIN is the major convening vehicle for governments, international NGO and private-sector stakeholders to promote food fortification. GAIN reports 'scaling up 36 large collaborations in 25 countries since 2002 to reach 400 million people with nutritionally enhanced products' ${ }^{(87)}$. GAIN aspires to mobilize \$US 700 million of private-sector investment through a Business Alliance ${ }^{(55,56)}$. GAIN supports partnerships with global food and beverage companies to stimulate market-based solutions that address malnutrition, produce commercial benefits for companies, and encourage economic development in low- and middle-income countries ${ }^{(55,56,87)}$.

Evaluations of food fortification programmes in lowincome countries suggest that cost-effective and sustainable results are feasible when there is close collaboration among the public sector to improve population health; the private sector, with expertise in food production, technology, marketing communications and consumer reach; and NGO that deliver programmes and services to vulnerable groups ${ }^{(88)}$. Independent evaluations of GAIN's Business Alliance are needed to understand the benefits and challenges of using a PPP approach to address micronutrient malnutrition.

\section{International Food \& Beverage Alliance and the} Healthy Weight Commitment Foundation to

prevent obesity

The WHO Global Strategies ${ }^{(31,58)}$ acknowledge that private-sector partners should play a central role in promoting healthy food and eating environments to prevent NCD. In 2008, eight leading food and beverage companies founded the International Food \& Beverage Alliance (IFBA) in response to rising obesity rates ${ }^{(83)}$. In 2009 , ten IFBA members with a combined annual revenues of \$US 350 billion $^{(35)}$ shared a report with $\mathrm{WHO}^{(89)}$, suggesting progress had been made to: (i) reformulate and develop new products to improve diets; (ii) provide clear nutrition information to consumers; (iii) extend responsible advertising and marketing pledges to children globally; (iv) raise awareness about balanced diets and increasing physical activity; and (v) support partnerships to promote healthy lifestyles. Independent evaluations have not confirmed IFBA's self-reported progress.

In 2009, the Healthy Weight Commitment Foundation (HWCF) was formed in response to the US obesity epidemic as an industry coalition comprised of food, beverage and food retail companies that partners with business-interest NGO (i.e. industry trade associations) and public-interest NGO. The HWCF partners have pledged to make measureable changes to reformulate and expand healthier products in the marketplace, to support worksite wellness, and to promote energy balance education to children in schools ${ }^{(84,90)}$. In 2010, the HWCF members partnered with private foundations and government through First Lady Michelle Obama's Lets Move! obesity prevention campaign ${ }^{(91)}$. An independent evaluation is underway by academic groups, funded by the Robert Wood Johnson Foundation, to assess the coalition's progress in making changes in the three settings.

\section{Assessing partnership risks and challenges}

All stakeholders involved in PPP are confronted with dilemmas that threaten their goals. PPP evaluations have identified risks that can undermine the appropriateness, effectiveness and credibility of alliances due to: displacing donor priorities with those of recipient countries; excluding certain stakeholders from decision making; neglecting to effectively address conflicts of interest and biases; raising insufficient resources to implement partnership activities and sustain alliances; and inadequately managing human resources $^{(61,92)}$.

Six challenges discussed below must be addressed to reduce risks to all partners: (i) balancing private commercial interests with public health interests; (ii) managing conflicts of interest and biases; (iii) ensuring that co-branded activities support healthy products and healthy eating environments; (iv) complying with ethical codes of conduct; (v) undertaking due diligence to assess partnership compatibility; and (vi) monitoring and evaluating partnership outcomes.

\section{Balancing commercial and public health interests}

Collaborative partnerships provide companies with commercial advantages, yet private commercial interests often conflict with public interests ${ }^{(92)}$ and balancing winloss outcomes is tough. A win-win outcome may be possible to address global food insecurity ${ }^{(32,52)}$; develop inexpensive and high-quality commercial, complementary food products and integrated marketing communications campaigns that address young child undernutrition in emerging markets ${ }^{(10,33,93)}$; drive product innovation for new consumers $^{(66)}$; build community disaster resilience ${ }^{(53)}$; improve the systematic delivery of humanitarian assistance ${ }^{(59)}$; 
and provide comprehensive integrated packages of nutrition interventions to reach malnourished populations during complex emergencies ${ }^{(60)}$. However, even these partnerships can have unintended consequences and not produce benefits for every partner or target population ${ }^{(29,36)}$. It is arguable whether markets can deliver both short-term financial returns for companies and long-term social, economic and health benefits to address the spectrum of global malnutrition challenges ${ }^{(29)}$.

Current agribusiness-sector models are more compatible with producing and distributing food as a response to hunger and food insecurity than reducing portion sizes or substantially reformulating food and beverage products to improve diet quality and prevent overconsumption ${ }^{(94)}$. Concerns relate to any marketing strategy that may increase consumers' brand loyalty for a company's unhealthy branded product line ${ }^{(94)}$ such as promoting bottled water or fortified products that influence the purchase and consumption of branded sugar-sweetened beverages or energydense snacks ${ }^{(40)}$. These are relevant concerns for consumers with limited discretionary household incomes, who are vulnerable to persuasive marketing practices and are disproportionately affected by obesity and NCD in emerging markets ${ }^{(36,40,95)}$. Risks arise when NGO facilitate companies' access to consumers and influential groups and when partners fail to monitor and evaluate partnership processes and outcomes.

PPP are influenced by global and national government structures. The Codex Alimentarius Commission uses international standards and strong intergovernmental oversight to protect consumer health by promoting global food safety and ensuring fair food trade practices ${ }^{(96)}$. Global PPP may identify advantages within the regulatory environment to enhance outcomes, such as providing standards to foster a competitive environment to move industry practices and entire food or beverage product portfolios towards desirable targets to achieve population health benefits ${ }^{(36,97)}$. Examples include the World Action on Salt \& Health, a voluntary global initiative that engages governments, industry and NGO to implement strategies to reduce the salt content of processed foods and $\mathrm{Na}$ consumption in populations ${ }^{(98)}$; and the Flour Fortification Initiative $^{(99)}$, an international network of public and private organizations in the specific context of it encouraging government-regulated and voluntary quality-control systems for Fe fortification of wheat flour to benefit populations in certain countries ${ }^{(100)}$.

Partners must develop mutual trust and open communication to assess where profit-driven activities and public health benefits overlap or conflict. NGO and privatesector companies could dedicate staff and sufficient resources to nurture and sustain partnerships that balance social and health investments with business profits ${ }^{(26)}$. Partners must also anticipate unintended consequences and collaborate to improve the nutrition and health outcomes of targeted populations.
Managing conflicts of interest and biases

NGO and partnering food, beverage and restaurant companies should seek to effectively manage conflicts of interest and biases to establish trustworthy relationships, allay public concerns about compromised partner integrity, reduce the risks to each partner's reputation and minimize unintended consequences for programmes or targeted populations.

Conflicts of interest may arise when NGO staff receive personal gifts or in-kind resources from companies to influence decision making, research or public positions ${ }^{(92,101-104)}$. Further, it is arguable that NGO may be susceptible to 'white hat bias',(105), a tendency to disregard facts and distort the truth to serve righteous ends.

Private-sector partners face challenges arising from managing self-dealing conflict of interest. A company's commercial activities may benefit from research generated through a partnership funded by the company's foundation, which may be legally required to act at arms length. Public trust and credibility may be diminished due to the apparent duplicity of private foundations' investments. For example, the Bill \& Melinda Gates Foundation has generously supported programmes targeting global health and undernutrition. At the same time, the Foundation has generated a portion of its wealth through direct investments in companies that produce and market products linked to rising obesity and NCD rates, including McDonald's Corporation and The Coca-Cola Company, and indirect investments in Coca-Cola, Kraft Foods and Nestlé through Berkshire Hathaway ${ }^{(92)}$.

These considerations do not necessarily preclude PPP but should rather be viewed as opportunities to be addressed to strengthen partnerships. Private-sector partners would be better able to address conflicts of interest by disclosing and improving their accountability for labour, environmental and health-related policies, practices and performance. NGO must be able to independently criticize a private-sector entity for issues unrelated to the partnership to fulfil an important watchdog function to hold governments and industry accountable for public health commitments by exposing non-compliance and inaction ${ }^{(24,29)}$.

Guidelines have been proposed to minimize conflicts of interest and biases related to industry-sponsored research with commercial applications ${ }^{(103)}$. Organizations could make partnership terms, outcomes and benefits more transparent and explicit through clearly written contracts; incorporate guidelines for managing conflicts of interest into governing bodies' bylaws; and widely promote written policies and an institutionalized process to standardize expectations for employees to disclose financial and nonfinancial industry relationships ${ }^{(92,101,104)}$.

Public health professionals and NGO staff who receive industry funding could reject payment or withdraw from institutional decision making ${ }^{(92,101)}$, decline to give industrysponsored presentations, avoid ghost-writing publications, 
Table 4 A tool to assess partnership compatibility between non-governmental organizations (NGO) and transnational food, beverage and restaurant companies to address global nutrition challenges (adapted from reference 27)

\begin{tabular}{|c|c|c|}
\hline Dimension & Assess partnership compatibility & Potential benefits \\
\hline Mission & $\begin{array}{l}\text { Is involvement in a partnership or social alliance expressing the company's mission } \\
\text { or vision? } \\
\text { Is the cause addressed by the partnership part of the NGO's core mission? }\end{array}$ & Shared priorities \\
\hline Resources & $\begin{array}{l}\text { Does each partner have resources that the other needs and would have difficulty } \\
\text { accessing themselves? } \\
\text { Are resources vital to create an advantage for each partner? }\end{array}$ & $\begin{array}{l}\text { Dependence and differential } \\
\text { advantage }\end{array}$ \\
\hline Management & $\begin{array}{l}\text { Do the leaders of the company and NGO have personal chemistry? } \\
\text { Do strong personal bonds exist among counterparts at multiple levels? }\end{array}$ & $\begin{array}{l}\text { Managerial engagement and } \\
\text { support }\end{array}$ \\
\hline Workforce & $\begin{array}{l}\text { Is there a fit between the company's workforce and the cause such that it has or } \\
\text { will develop an affinity for the cause and become involved in grassroots efforts? }\end{array}$ & $\begin{array}{l}\text { Enhancing organizational } \\
\text { identification } \\
\text { Providing volunteer support }\end{array}$ \\
\hline Target market & $\begin{array}{l}\text { Is there a demographic, geographic and/or psychographic fit between the members of } \\
\text { the target market such that they have or will develop an affinity for the cause? } \\
\text { Can the NGO's constituents influence the company's brand or products? }\end{array}$ & $\begin{array}{l}\text { Creating differential } \\
\text { advantage } \\
\text { Providing volunteer support }\end{array}$ \\
\hline Product or cause & $\begin{array}{l}\text { Can endorsements be created that benefit all partners? } \\
\text { Does the product or cause-marketing arrangement meet healthful criteria and } \\
\text { support public health goals? } \\
\text { Are there unintended consequences or detrimental effects related to product or } \\
\text { event co-sponsorship, or contributions-in-kind? } \\
\text { Is the compatible positioning between the company and the NGO based on } \\
\text { strategic similarity? }\end{array}$ & $\begin{array}{l}\text { Creating value through } \\
\text { co-branding opportunities }\end{array}$ \\
\hline $\begin{array}{l}\text { Cultural fit and } \\
\text { values }\end{array}$ & Are the organizational values of the partners compatible? & $\begin{array}{l}\text { Ease of implementation and } \\
\text { management }\end{array}$ \\
\hline Cycle & $\begin{array}{l}\text { Are the business cycles of the company and fundraising cycles of the NGO partner } \\
\text { aligned? }\end{array}$ & Timing congruence \\
\hline Evaluation & $\begin{array}{l}\text { Have partners specified how they will measure the effectiveness of the alliance? } \\
\text { Have partners developed mutual or joint measures of success? } \\
\text { Can partners support each other's primary measure of success? }\end{array}$ & Shared perception of success \\
\hline
\end{tabular}

and turn down consulting arrangements unless governed by clearly written contracts ${ }^{(104,106)}$.

Using co-branded activities to support bealthy

products and healthful diets

Co-branding is apparent in all types of partnerships. NGO should develop criteria and systems for accepting company donations and contributions in-kind that are appropriate to their mission, adhere to standard healthy nutritional guidelines, support local sustainable markets and food systems, align with desirable items distributed through their programmes, and require minimal handling or transportation costs ${ }^{(59,72)}$.

NGO may be attracted by food and beverage company sponsorship and cause marketing to secure unrestricted funds to support professional societies and conferences $^{(42,101,107)}$, nutrition research ${ }^{(103,108)}$, programmes $^{(109)}$ and sporting events ${ }^{(110)}$. Sponsorship is a commercial activity to promote a company's brand, not a philanthropic gift ${ }^{(70,71)}$. Risks arise when partners either fail to effectively manage conflicts of interest or engage in duplicitous activities such as concurrent lobbying of legislators to support issues that undermine public health goals $^{(111,112)}$.

One approach to facilitate decision making about co-sponsoring events is to appoint a brand advisory committee to use a risk-assessment framework with specific criteria to assess the brand, nutrient and event profiles; company marketing and distribution practices; and contextual relevance ${ }^{(113)}$. Obtaining accurate proprietary information about a company's marketing and distribution practices is an ongoing challenge.

Public perceptions about global food, beverage and restaurant company sponsorship favour branded products that have healthy nutritional profiles compared with products with less healthy profiles (i.e. hamburgers, pizza, chocolate bars, salty snacks and sweetened beverages) ${ }^{(110)}$. NGO and other partners could develop clear criteria about co-sponsored arrangements and align all integrated marketing communications with sponsored products or events to consistently promote public health goals ${ }^{(110)}$.

\section{Complying with ethical codes of conduct}

Codes of conduct raise and maintain public awareness about specific issues, build public pressure to change practices that are detrimental to society, and encourage debate about appropriate standards for corporate conduct $^{(114)}$. Most global food and beverage companies have generally complied with legally binding treaties, such as the UN Convention on the Rights of the Child ${ }^{(115)}$; and voluntary codes of conduct, such as industry selfregulatory programmes to advertise or market responsibly to children ${ }^{(116)}$ and the International Code of Marketing of Breast-Milk Substitutes ${ }^{(117)}$. In the latter case, there are notable exceptions documented by independent groups when certain companies' marketing practices continuously violate the Code ${ }^{(118-120)}$ while industry-supported, 


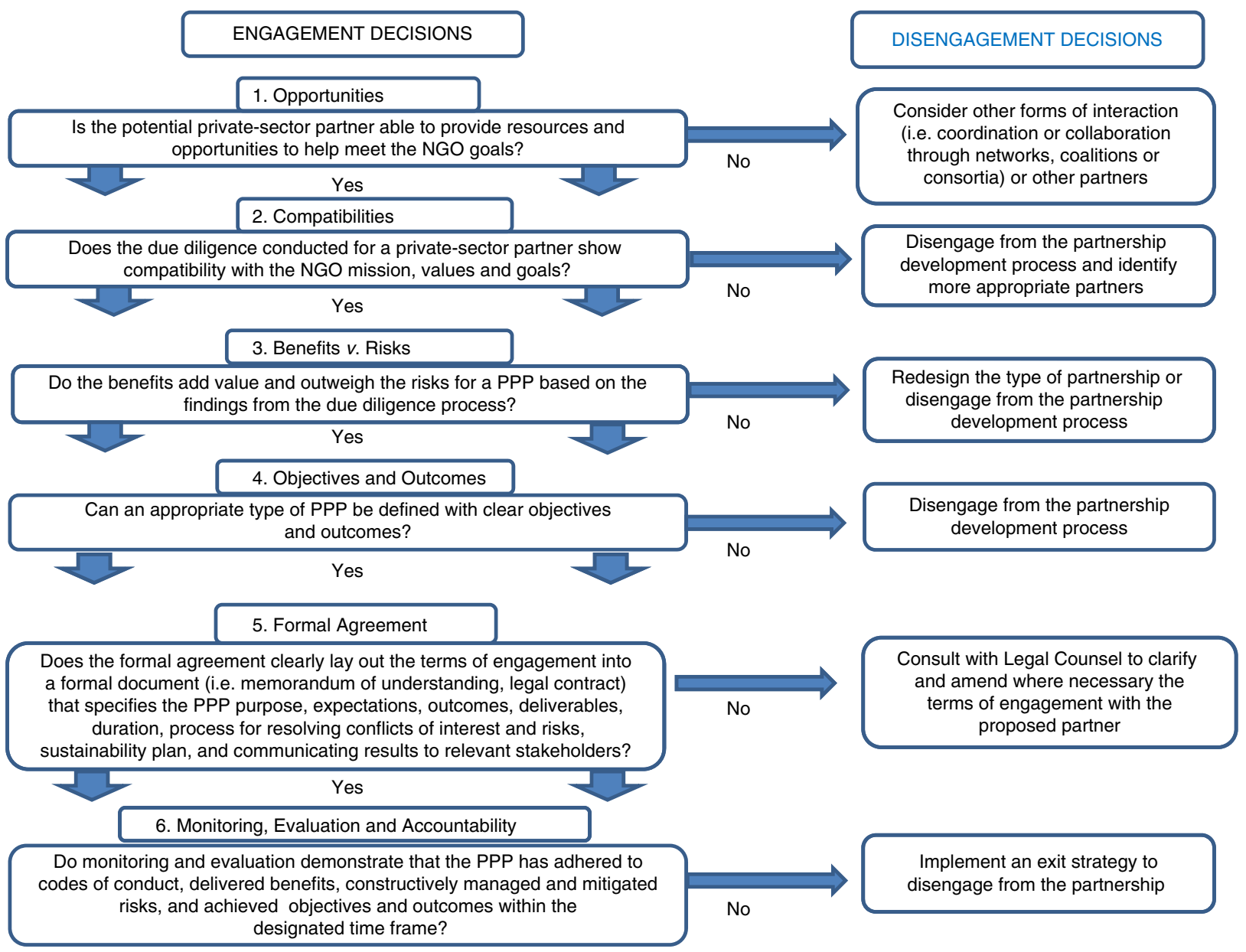

Fig. 2 (colour online) A benefit-risk decision-making pathway* for non-governmental organizations (NGO) to engage with transnational food, beverage and restaurant companies through public-private partnerships (PPP) to address the global double burden of malnutrition. *For an NGO to put this decision-making pathway into practice, steps 1-5 are non-negotiable and all need to be 'yes' before proceeding with a potential PPP. Step 6 is the ongoing and final decision making required to ensure that the PPP will optimize benefits and minimize risks to all partners and target populations (adapted from WHO $(2010)^{(18)}$, VicHealth $(2008)^{(62)}$, Partnership Governance and Accountability Initiative $(2010)^{(132)}$ and Parramatta City Council (2006) ${ }^{(133)}$ )

third-party verification mechanisms confirm company compliance ${ }^{(121,122)}$. These issues cause tension, erode public trust and respect for partners, and diminish the effect of voluntary codes.

Several company pledges have been deemed inadequate to protect children's health and well-being. Many companies' current marketing practices promote unhealthy products that undermine children's right to a healthful diet ${ }^{(115)}$. Independent evaluations ${ }^{(123-127)}$ have documented questionable marketing practices of global companies participating in GAIN, IFBA and HWCF (Table 3) that have not yet been adequately addressed by industry self-regulatory programmes or individual companies, or dealt with in a coordinated way among public-interest NGO. Companies have used their own nutrition guidelines for product reformulation and varied nutrition standards to define healthy products; applied more lenient nutrition criteria for products they manufacture; varied self-regulatory marketing pledges between countries and regions; lacked clear policies on marketing to children and adolescents; excluded packaging, point-of-sale materials, in-school marketing, contributions inkind and new media from pledges; and made no commitments to stop marketing unhealthy products to children through their parents.

Shared principles have been proposed for stakeholders to promote infant and young child nutrition ${ }^{(93)}$ and reduce the commercial promotion of unhealthy products to children and adolescents ${ }^{(128)}$. Industry self-regulatory programmes are likely to be effective when they establish and widely promote transparent regulatory standards with input from diverse stakeholders, develop meaningful objectives and benchmarks, institute a mandatory public reporting mechanism to show compliance with voluntary codes, and allow evaluations to be conducted by independent groups ${ }^{(129)}$. The timing is crucial for all stakeholders to implement, monitor and evaluate these principles given WHO's global resolution recommending that Member States substantially reduce marketing 
practices that promote unhealthy food and non-alcoholic beverage products to children and adolescents ${ }^{(130)}$.

\section{Conducting due diligence to assess partnership compatibility and evaluate outcomes}

Frameworks and tools are available, including compatibility assessment criteria (Table 4) and a benefit-risk decisionmaking pathway (Fig. 2), to help NGO conduct due diligence to select appropriate partnerships for collaborations that promote synergy, transparent decision making and accountability for specific outcomes ${ }^{(27,62,67,131-133)}$.

NGO may already have developed corporate social responsibility profiling, partnership criteria and institutionalized guidelines governing how they partner with companies that manufacture socially unacceptable products (i.e. weapons, tobacco) or engage in egregious practices (i.e. child exploitation, gambling and extractive mining). NGO should also develop partnership profiling, guidelines and criteria to evaluate the totality of partnership activities with transnational food, beverage and restaurant companies, including their compliance with voluntary codes ${ }^{(131-133)}$ and ensure that PPP are harmonized with country strategies, institutions and processes.

\section{Conclusions}

The current paper describes partnership opportunities, benefits and challenges; and tools and approaches to help NGO engage with the private sector to effectively address global nutrition challenges. While partnerships may present certain benefits, not all PPP will produce benefits for every partner or target population. PPP challenges include: balancing private commercial interests with public health interests; managing conflicts of interest and biases; ensuring that co-branded activities support healthy products and healthy eating environments; complying with ethical codes of conduct; conducting due diligence; and evaluating partnership compatibility and outcomes. NGO should adopt a systematic and transparent approach using available tools and processes to maximize benefits and minimize risks related to partnering with transnational food, beverage and restaurant companies to effectively target the global double burden of malnutrition.

\section{Acknowledgements}

Sources of funding: V.I.K. received PhD scholarship support to complete this paper through Deakin University's Population Health Strategic Research Centre in the School of Health and Social Development. The other authors declare that they received no additional funding to develop this paper. Conflict of interest: V.I.K., M.L., P.J.H., M.A.J. and B.S. have no conflict of interest. P.B.H. is employed by Save the Children, which in the USA has received funding to support several programme areas. Among these supporters are The Bill and Melinda Gates Foundation, General Mills Foundation, Kidfresh, Kraft Foods and Kraft Foundation, PepsiCo Foundation, Wal-Mart Foundation and the Wm. Wrigley Jr. Company Foundation. The views expressed here are those of the authors and not necessarily those of Save the Children Federation, Inc. Author contributions: V.I.K. developed the initial concept, conducted the literature review, and wrote the first draft of the paper. P.B.H., P.J.H., M.L., M.A.J. and B.S. further developed the concepts, identified additional references, and contributed to subsequent drafts of the paper. All authors read and approved the final manuscript. Acknowledgements: The authors are grateful for the insightful comments provided by the anonymous reviewers. They also thank Drs Bill Dietz, Cecily Hunter, Shiriki Kumanyika and Andre Renzaho, as well as Sana Chehini, Adrian Ng'asi and Brendan Wackenreuter, for providing helpful comments on earlier drafts of this paper.

\section{References}

1. McLachlan M \& Garrett J (2008) Nutrition change strategies: the new frontier. Public Health Nutr 11, 1063-1075.

2. United Nations Standing Committee on Nutrition (2006) Tackling the Double Burden of Malnutrition: A Global Agenda. http://www.unscn.org/layout/modules/resources/ files/scnnews32.pdf (accessed November 2010).

3. Food and Agriculture Organization of the United Nations (2006) The Double Burden of Malnutrition: Case Studies From Six Developing Countries. FAO Food and Nutrition Papemo. 84. Rome: FAO; available at ftp://ftp.fao.org/ docrep/fao/009/a0442e/a0442e00.pdf

4. Uauy R, Kain J, Mericq V et al. (2008) Nutrition, child growth, and chronic disease prevention. Ann Med 40, 11-20.

5. James P, Norum KR, Smitasiri S et al. (2000) Ending Malnutrition by 2020: An Agenda for Change in the Millennium. Final Report to the ACC/SCN by the Commission on the Nutrition Challenges of the 21st Century. Executive summary. http://www.unscn.org/layout/modules/resources/ files/2020Report_1.pdf (accessed February 2011).

6. United Nations System Standing Committee on Nutrition (2011) Sixth Report on the World Nutrition Situation: Progress in Nutrition. Geneva: UNSCN; available at http://www.unscn.org/files/Publications/RWNS6/report/SCN_ report.pdf

7. Food and Agriculture Organization of the United Nations (2010) The State of Food Insecurity in the World: Addressing food insecurity in protracted crises. Rome: FAO; available at http://www.fao.org/docrep/013/i1683e/ i1683e.pdf

8. Black RE, Allen LH, Bhutta ZA et al. (2008) Maternal and child undernutrition: global and regional exposures and health consequences. Lancet 371, 243-260.

9. Micronutrient Initiative (2009) Investing in the Future: A United Call to Action on Vitamin and Mineral Deficiencies. Global Report 2009. http://www.unitedcalltoaction.org/ documents/Investing_in_the_future.pdf (accessed November 2010).

10. Engle P \& Huffman SL (2010) Growing children's bodies and minds: maximizing child nutrition and development. Food Nutr Bull 31, 2 Suppl., S186-S197.

11. de Onis M, Blössner M \& Borghi E (2010) Global prevalence and trends of overweight and obesity among pre-school children. Am J Clin Nutr 92, 1257-1264. 
12. Wang Y \& Lobstein T (2006) Worldwide trends in childhood overweight and obesity. Int J Pediatr Obes 1, 11-25.

13. Finucane MM, Stevens GA, Cowan MJ et al.; on behalf of the Global Burden of Metabolic Risk Factors of Chronic Diseases Collaborating Group (Body Mass Index) (2011) National, regional, and global trends in body-mass index since 1980: systematic analysis of health examination surveys and epidemiological studies with 960 country-years and 9.1 million participants. Lancet $\mathbf{3 7 7}$, 557-567.

14. Beaglehole R, Bonita R, Horton R et al.; Lancet NCD Action Group; NCD Alliance (2011) Priority actions for the noncommunicable disease crisis. Lancet 377, 1438-1447.

15. World Health Organization (2011) Global Status Report on Noncommunicable Diseases 2010. Geneva: WHO; available at http://whqlibdoc.who.int/publications/2011/ 9789240686458_eng.pdf

16. United Nations Standing Committee on Nutrition (2010) Scaling Up Nutrition: A Framework for Action. Based on a series of consultations hosted by the Center for Global Development, the International Conference on Nutrition, USAID, UNICEF and the World Bank. http://www.unscn. org/files/Annual_Sessions/2009_Brussels/SUN_FRAMEWORK_ FOR_ACTION_NUTRITION_POLICY.PDF (accessed November 2010).

17. Morris SS, Cogill B \& Uauy R; Maternal and Child Undernutrition Study Group (2008) Effective international action against undernutrition: why has it proven so difficult and what can be done to accelerate progress? Lancet $\mathbf{3 7 1}$, 608-621.

18. World Health Organization (2010) Partnerships. WHA63.10, Agenda item 18.1, 21 May. http://apps.who.int/gb/ebwha/pdf_ files/WHA63/A63_R10-en.pdf (accessed November 2010).

19. Pan American Health Organization/World Health Organization (2009) Partners' Forum for Action: Prevention of Chronic Diseases \& Promotion of Healthy Lifestyles. http:// new.paho.org/hq/index.php?option $=$ com_content\&task $=$ view\&id $=2067 \&$ Itemid $=1826$ (accessed November 2010).

20. United Nations (2009) Strengthening the Global Partnership for Development in a Time of Crisis: Millennium Development Gap Task Force Report. http://www.un.org/ millenniumgoals/pdf/MDG_Gap_\%20Task_Force_\%20Report_ 2009.pdf (accessed November 2010).

21. Daar AS, Singer PA, Persad DL et al. (2007) Grand challenges in chronic non-communicable diseases. Nature 450, 494-496.

22. Institute of Medicine (2009) The US Commitment to Global Health: Recommendations for the Public and Private Sector. Washington, DC: The National Academies Press.

23. Global NGO Network (2010) Definition of NGOs. http:// www.ngo.org/ngoinfo/define.html (accessed April 2011).

24. World Health Organization (2002) WHO's Interactions with Civil Society and Nongovernmental Organizations. Civil Society Initiative. External Relations and Governing Bodies. Geneva: WHO; available at http://www.who.int/ civilsociety/documents/en/RevreportE.pdf

25. World Health Organization (2011) Public-Private Partnerships for Health. http://www.who.int/trade/glossary/ story077/en/index.html (accessed April 2011).

26. Austin JE (2000) Strategic collaboration between nonprofits and business. Nonprofit Voluntary Sector Q 29, 69-97.

27. Kraak VI \& Story M (2010) A public health perspective on healthy lifestyles and public-private partnerships for global childhood obesity prevention. J Am Diet Assoc 110, 192-200.

28. Dixon J, Sindall C \& Banwell C (2004) Exploring the intersectoral partnerships guiding Australia's dietary advice. Health Promot Int 19, 5-13.

29. Richter J (2004) Public-Private Partnerships and International Health Policy-Making: How Can Public Interests be
Safeguarded? Geneva: World Health Organization/P.Virot; available at http://formin.finland.fi/public/download.aspx?ID= 12360\&GUID $=\{3556$ FE5F-6CBC-4000-86F3-99EBFD2778FC $\}$

30. United Nations General Assembly (2009) Report of the Special Rapporteur on the right to food, Olivier De Schutter. Agribusiness and the right to food. Human Rights Council, 13th Session. http://www2.ohchr.org/english/ bodies/hrcouncil/docs/13session/A-HRC-13-33.pdf (accessed November 2010).

31. World Health Organization (2004) Global Strategy on Diet, Physical Activity, and Health. Geneva: WHO; available at http://www.who.int/gb/ebwha/pdf_files/ WHA57/A57_R17-en.pdf

32. US Government (2011) Feed the Future Guide: A Summary. http://www.feedthefuture.gov/FTF_Guide_summary.pdf (accessed March 2011).

33. Wojcicki JM \& Heyman MB (2010) Malnutrition and the role of the soft drink industry in improving child health in subSahara Africa. Pediatrics 126, e1-e5.

34. Yach D, Feldman ZA, Bradley DG et al. (2010) Can the food industry help tackle the growing global burden of undernutrition? Am J Public Health 100, 974-980.

35. Yach D, Khan M, Bradley D et al. (2010) The role and challenges of the food industry in addressing chronic disease. Global Health 6, 10.

36. Monteiro CA, Gomes FS \& Cannon G (2010) The snack attack. Am J Public Health 100, 975-981.

37. Ludwig DS \& Nestle M (2008) Can the food industry play a constructive role in the obesity epidemic? JAMA 15, $1808-1811$.

38. Koplan JP \& Brownell KD (2010) Response of the food and beverage industry to the obesity threat. JAMA $\mathbf{3 0 4}$, 1487-1488.

39. Freedhoff Y \& Hébert PC (2011) Partnerships between health organizations and the food industry risk derailing public health nutrition. CMAJ 183, 291-292.

40. Monteiro CA, Gomes FS \& Cannon G (2010) Can the soft drink industry prevent child malnutrition? No way (Letter to the editor). Pediatrics, 14 November. http://pediatrics.aap publications.org/content/126/6/e1617.long/reply\#pediatrics_ el_50847 (accessed August 2011).

41. Gilmore AB, Savell E \& Collin J (2011) Public health, corporations and the New Responsibility Deal: promoting partnerships with vectors of disease? J Public Health 33, 2-4.

42. Oshaug A (2009) What is the food and drink industry doing in nutrition conferences? Public Health Nutrition 12, 1019-1020.

43. Neuman W (2010) Save the Children breaks with soda tax effort. The New York Times, 14 December; available at http://www.nytimes.com/2010/12/15/business/15soda.html

44. Shields J (2011) Big Beverage gives $\$ 10$ million to Children's Hospital of Philadelphia (CHOP). The Philadelphia Inquirer Online, 16 March. http://www.philly.com/philly/blogs/ heardinthehall/118077483.html (accessed April 2011).

45. World Health Organization (2000) Guidelines on Working with the Private Sector to Achieve Health Outcomes. Executive Board 107th Session. EB107/20, 30 November. http://www.searo.who.int/LinkFiles/Guidelines_on_Resource_ Mobilization_ee20.pdf (accessed June 2011).

46. United Nations Standing Committee on Nutrition (2007) A Draft Proposal for Initiating SCN Private Sector Engagement, 12 February. http://www.unscn.org/en/mandate/ private_sector/ (accessed November 2010).

47. Evans D \& Killoran A (2000) Tackling health inequalities through partnership working: learning from a realistic evaluation. Crit Public Health 10, 125-140.

48. Gehner M, Matlin SA \& Sundaram L (2008) Health Partnerships Review: Focusing Collaborative Efforts on Research and Innovation for the Health of the Poor. 
Geneva: Global Forum for Health Research; available at http://www.globalforumhealth.org/Media-Publications/ Publications/Health-Partnerships-Review

49. The International Bank for Reconstruction and Development/ The World Bank (2011) Global Monitoring Report 2011. Improving the Odds of Achieving the MDGs. Washington, DC: The World Bank; available at http://siteresources. worldbank.org/INTGLOMONREP2011/Resources/78561311302708588094/GMR2011-CompleteReport.pdf

50. Widdus R (2001) Public-private partnerships for health: their main targets, their diversity, and their future directions. Bull World Health Organ 79, 713-720.

51. Yum! Brands Inc. (2010) World Hunger Relief 2011: From Hunger to Hope. http://www.fromhungertohope.com/ about/ (accessed May 2011).

52. US Agency for International Development (2011) USAID Administrator Highlights Private Sector Partnerships to Reduce Hunger and Poverty at the World Economic Forum. Washington, DC: USAID; available at http://www.usaid. gov/press/releases/2011/pr110128.html

53. Committee on Private-Public Sector Collaboration to Enhance Community Disaster Resilience, Geographical Science Committee, National Research Council (2010) Building Community Disaster Resilience through PrivatePublic Collaboration. Washington, DC: The National Academies Press.

54. US Agency for International Development (2009) Two Decades of Progress: USAID's Child Survival and Maternal Health Program. Washington, DC: USAID; available at http://pdf.usaid.gov/pdf_docs/PDACN044.pdf

55. Global Alliance for Improved Nutrition (2010) Partnerships and Collaboration. Summary of the Workshop. Business Seeking Solutions to the Fight Against Malnutrition. 4th GAIN Business Alliance Forum 25-26 May, Dubai, United Arab Emirates. http://www.gainhealth.org/sites/default/ files $/ 160610 \% 20$ GAIN\%20Insight $\% 20$ Meeting $\% 20$ Report $\% 20$ FINAL_0.pdf (accessed July 2011).

56. Global Alliance for Improved Nutrition (2009) Annual Report 2008-2009. http://www.gainhealth.org/sites/default/ files/AR_08-09_web_0.pdf (accessed November 2010).

57. US Agency for International Development (2008) Working Toward the Goal of Reducing Maternal and Child Mortality: USAID Programming and Response to FY08 Appropriations. http://pdf.usaid.gov/pdf_docs/PDACL707.pdf (accessed November 2010).

58. World Health Organization (2008) 2008-2013 Action Plan for the Global Strategy for the Prevention and Control of Noncommunicable Diseases: Prevent and Control Cardiovascular Diseases, Cancers, Chronic Respiratory Diseases and Diabetes. Geneva: WHO; available at http://whqlibdoc. who.int/publications/2009/9789241597418_eng.pdf

59. Thomas A \& Fritz L (2006) Disaster relief, inc. Harv Bus Rev 84, 114-122, 158.

60. Webb P (2009) Malnutrition in emergencies: the framing of nutrition concerns in the humanitarian appeals process, 1992 to 2009. Food Nutr Bull 30, 379-389.

61. Buse K \& Harmer AM (2007) Seven habits of highly effective global public-private health partnerships: practice and potential. Soc Sci Med 64, 259-271.

62. VicHealth (2008) The Partnerships Analysis Tool for Partners in Health Promotion. Australia: Victoria Health Promotion Foundation; available at http://www.vichealth.vic.gov.au/ / media/ResourceCentre/PublicationsandResources/General/ VHP\%20part\%20toollow\%20res.ashx

63. Fulton K, Kasper G \& Kibbe B (2010) What's Next for Philanthropy: Acting Bigger and Adapting Better in a Networked World. http://monitorinstitute.com/downloads/ Whats_Next_for_Philanthropy.pdf (accessed November 2010).

64. Conway MD, Gupta SE \& Prakesh S (2006) Building better partnerships for global health. McKinsey $Q \mathbf{1 2}, 1-8$.
65. Milward HB \& Provan KG (2006) A Manager's Guide to Choosing and Using Collaborative Networks. Washington, DC: The IBM Center for the Business of Government; available at http://www.businessofgovernment.org/sites/ default/files/CollaborativeNetworks.pdf

66. Traitler H, Watzke HJ \& Saguy S (2011) Reinventing R\&D in an open innovation ecosystem. J Food Sci 76, R62-R68.

67. Lasker RD, Weiss ES \& Miller R (2001) Partnership synergy: a practical framework for studying and strengthening the collaborative advantage. Millbank $Q$ 79, 179-205.

68. Yum! Brands (2008) Serving the World. http://www. yum.com/responsibility/pdf/yum08csrrpt.pdf (accessed March 2011).

69. Burger King (2009) BK Positive Steps: Fiscal 2009 Corporate Responsibility Report. http://www.bk.com/ cms/en/us/cms_out/digital_assets/files/pages/BK_CR_Report. pdf (accessed March 2011).

70. World Health Organization (2003, updated reprint 2004, 2005) WHO Framework Convention on Tobacco Control. Geneva: WHO; available at http://whqlibdoc.who.int/ publications/2003/9241591013.pdf

71. Rundall P (1998) Ethical debate: should industry sponsor research? How much research in infant feeding comes from unethical marketing? BMJ 317, 338-339.

72. The Business Dictionary (2011) Cause-Related Marketing and Contributions-in-Kind. http://www.businessdictionary. com/ (accessed April 2011)

73. Save the Children (2009) PepsiCo Foundation Announces Grant to Save the Children to Address Malnutrition in Developing Nations. http://www.csrwire.com/press_releases/ 15993-PepsiCo-Foundation-Announces-Grant-to-Save-theChildren-to-Address-Malnutrition-in-Developing-Nations (accessed February 2011)

74. Save the Children (2009) Kraft Foods and Save the Children Team up to Fight Malnutrition in Indonesia and the Philippines. http://www.csrwire.com/press_releases/13553Video-Kraft-Foods-and-Save-the-Children-Team-Up-to-FightMalnutrition-in-Indonesia-and-Philippines-in-Commemorationof-World-Health-Day (accessed February 2011).

75. PepsiCo (2009) PepsiCo Foundation and United Nations World Food Programme Announce Partnership to Enhance Humanitarian Relief Delivery Around the World. http:// www.pepsico.com/PressRelease/PepsiCo-Foundation-andUnited-Nations-World-Food-Programme-Announce-Partnership06162009.html (accessed July 2011).

76. The Coca-Cola Company (2011) The Coca-Cola Company and International Federation of Red Cross And Red Crescent Societies Launch Global Partnership. http://www.thecocacolacompany.com/dynamic/press_center/2011/01/red-crossand-red-crescent-societies-global-partnership.html (accessed February 2011).

77. Sahud HB, Binns HJ, Meadow WL et al. (2006) Marketing fast food: impact of fast food restaurants in children's hospitals. Pediatrics 118, 2290-2297.

78. The Coca-Cola Company (2011) Coca-Cola opens happiness with its new 'eight-pack' of athletes for London 2012 Olympic Games. http://www.thecoca-colacompany.com/ dynamic/press_center/2011/05/eight-pack-of-athletes-forlondon-2012-olympic-games.html (accessed May 2011).

79. McDonald's Corporation (2010) McDonald's 2009 Worldwide Corporate Responsibility Online Report: The Values We Bring to the Table. http://www.aboutmcdonalds.com/ $\mathrm{mcd} / \mathrm{csr} /$ report/overview.-RightParaContentTout-43872ReportsLinkList-28982-File1.tmp/mcd052_2009report_v6.pdf (accessed March 2011).

80. Collin J \& MacKenzie R (2006) The World Cup, sport sponsorship, and health. Lancet 367, 1964-1966.

81. Krämer A (2006) World Championship 2006 in Germany: sponsorship through Coca Cola, McDonald's, AnheuserBusch. Eur J Public Health 16, 682. 
82. Anon (2010) Trick or treat or UNICEF Canada. Lancet 376, 1514.

83. International Food \& Beverage Alliance (2011) Collaborating, educating and innovating to help consumers achieve balanced diets and healthy lifestyles. https://www.ifballiance. org/ (accessed August 2011).

84. Healthy Weight Commitment Foundation (2011) 2010 Annual Review. http://www.healthyweightcommit.org/HWCF_ AnnualReport/HWCF_2010_AR.pdf (accessed November 2010).

85. Maternal Child Health Integrated Programs (2011) MCHIP partners. http://www.mchip.net/node/14 (accessed March 2011)

86. Saving Lives at Birth (2011) A Grand Challenge for Development. http://savinglivesatbirth.net/ (accessed June 2011)

87. Global Alliance for Improved Nutrition (2011) About GAIN. http://www.gainhealth.org/about-gain (accessed May 2011)

88. Mannar MG \& van Ameringen M (2003) Role of publicprivate partnership in micronutrient food fortification. Food Nutr Bull 24, 4 Suppl., S151-S154.

89. International Food, Beverage Alliance (2009) Progress Report on the International Food to Action under the 2004 Global Strategy on Diet. https://www.ifballiance.org/ sites/default/files/IFBA $\% 27 \mathrm{~s} \% 2$ Progress $\% 20$ Report $\% 20$ to $\%$ 20DG\%20Dr\%20Chan\%20\%28November\%202009\%29.pdf (accessed November 2010).

90. Healthy Weight Commitment Foundation (2010) Fighting Obesity by Balancing Calories In with Calories Out. http://www.healthyweightcommit.org/about/overview/ (accessed November 2010).

91. The White House Office of the First Lady (2010) Remarks by the First Lady at Healthy Weight Announcement Press Conference. http://www.whitehouse.gov/the-press-office/ remarks-first-lady-healthy-weight-announcement-pressconference (accessed November 2010).

92. Stuckler D, Basu S \& McKee M (2011) Global health philanthropy and institutional relationships: how should conflicts of interest be addressed? PLOS Med 8, 1-10.

93. Singh JA, Daar AS \& Singer PA (2010) Shared principles of ethics for infant and young child nutrition in the developing world. BMC Public Health 10, 321.

94. Kraak VI, Kumanyika SK \& Story M (2009) The commercial marketing of 'healthy lifestyles' to address the global child and adolescent obesity pandemic: prospects, pitfalls and priorities. Public Health Nutr 12, 2027-2036.

95. Taylor FC, Satija A, Khurana S et al. (2011) Pepsi and Coca Cola in Delhi, India: availability, price and sales. Public Health Nutr 14, 653-660.

96. Somogyi A, Hathcock J, Biesalski HK et al. (2011) Scientific issues related to Codex Alimentarius goals: a review of principles, with examples. Regul Toxicol Pharmacol 60, 161-164.

97. Richter J (2004) Public-private partnerships for health: a trend with no alternatives? Development 47, 43-48.

98. World Action on Salt \& Health (2011) WASH introduction. http://www.worldactiononsalt.com/ (accessed August 2011).

99. Maberly G, Grummer-Strawn L, Jefferds ME et al. (2008) Trends in wheat-flour fortification with folic acid and iron - worldwide, 2004 and 2007. MMWR Morb Mortal Wkly Rep 57, 8-10.

100. Johnson QW \& Wesley AS (2010) Miller's best/enhanced practices for flour fortification at the flour mill. Food Nutr Bull 31, 1 Suppl., S75-S85.

101. Brody H (2010) Professional medical organizations and commercial conflicts of interest: ethical issues. Ann Fam Med 8, 354-358.

102. Ferris LE \& Fletcher RH (2010) Conflict of interest in peerreviewed medical journals: the World Association of Medical Editors' position on a challenging problem. Pharmacogn Mag 6, 71-73.
103. Rowe S, Alexander N, Clydesdale FM et al. (2009) Funding food science and nutrition research: financial conflicts and scientific integrity. Nutr Rev 67, 264-272.

104. Brennan TA, Rothman DJ, Blank L et al. (2006) Health industry practices that create conflicts of interest: a policy proposal for academic medical centers. JAMA 295, 429-433.

105. Cope MB \& Allison DB (2010) White hat bias: examples of its presence in obesity research and a call for renewed commitment to faithfulness in research reporting. Int $\mathrm{J}$ Obes (Lond) 34, 84-88.

106. Institute of Medicine (2009) Conflict of Interest in Medical Research, Education, and Practice. Washington, DC: The National Academies Press.

107. Tobin DS, Dwyer J \& Gussow JD (1992) Cooperative relationships between professional societies and the food industry: opportunities or problems? Nutr Rev $\mathbf{5 0}$, 300-310.

108. Nestle M (2001) Food company sponsorship of nutrition research and professional activities: a conflict of interest? Public Health Nutr 4, 1015-1022.

109. James JE (2002) Third-party threats to research integrity in public-private partnerships. Addiction 97, 1251-1255.

110. Danylchuk KE \& MacIntosh E (2009) Food and nonalcoholic beverage sponsorship of sporting events: the link to the obesity issue. Sport Mark $Q \mathbf{1 8}, 5-13$.

111. Spolar C, Eaton J (2009) As soda tax bubbles up, food lobby mobilizes industry groups spent more than \$24 million this year to sway lawmakers. Huffington Post, 4 November. http://huffpostfund.org/stories/ 2009/11/soda-tax-bubbles-food-lobby-mobilizes (accessed November 2010).

112. Corporate Europe Observatory (2010) A Red Light for Consumer Information: The Food Industry's $€ 1$-billion Campaign to Block Health Warnings on Food. http:// www.corporateeurope.org/lobbycracy/content/2010/06/ red-light-consumer-information (accessed November 2010).

113. Healthway (2010) Sponsorship. http://www.healthway. wa.gov.au/default.aspx?MenuID=709 (accessed November 2010).

114. Organization for Economic Co-operation and Development (2001) Codes of Corporate Conduct: Expanded Review of their Contents. http://www.oecd.org/dataoecd/ 57/24/1922656.pdf (accessed June 2011).

115. United Nations High Commissioner for Human Rights (1989) Convention on the Rights of the Child. http:// www2.ohchr.org/english/law/pdf/crc.pdf (accessed November 2010).

116. Kolish ED, Enright M \& Burke C (2010) The Children's Food \& Beverage Advertising Initiative in Action. A Report on Compliance and Implementation During 2009. Council of the Better Business Bureaus, Inc. http://www.bbb.org/ us/storage/0/Shared\%20Documents/BBBwithlinks.pdf (accessed March 2011).

117. World Health Organization (1981) The International Code of Marketing of Breast-milk Substitutes. Geneva: WHO; available at http://www.who.int/nutrition/publications/ code_english.pdf

118. Aguayo VM, Ross JS, Kanon S et al. (2003) Monitoring compliance with the International Code of Marketing of Breastmilk Substitutes in West Africa: multisite cross sectional survey in Togo and Burkina Faso. BMJ 326, 127-133.

119. International Baby Food Action Network (2009) State of the Code by Company 2009. http://www.ibfan.org/codepublications.html (accessed November 2010).

120. Save the Children UK (2007) A Generation On: Baby Milk Marketing Still Putting Children's Lives at Risk. London: Save the Children UK; available at http://www.savethe children.org.uk/en/docs/a_generation_on.pdf

121. Nestlé S.A. (2009) Nestlé Creating Shared Value Report 2009. Vevey: Nestlé S.A.; available at http://www2. 
nestle.com/Common/NestleDocuments/Documents/Reports/ CSV\%20reports/Global\%20report\%202009/Global_report_ 2009_GB.pdf

122. FTSE (2009) FTSE4Good Breast-Milk Substitute Criteria. http://www.ftse.com/Indices/FTSE4Good_Index_Series/ Downloads/FTSE4Good_Breast_Milk_Substitute_Criteria. pdf (accessed November 2010).

123. Lang T, Rayner G \& Kaelin E (2006) The Food Industry, Diet, Physical Activity and Health: A Review of the Reported Commitments and Practice of 25 of the World's Largest Food Companies. London: Centre for Food Policy, City University; available at http://www.city.ac.uk/press/ The $\% 20$ Food $\% 20$ Industry $\% 20$ Diet $\% 20$ Physical $\% 20$ Activity $\% 20$ and $\% 20$ Health.pdf

124. Langlois A \& Crossley $\mathrm{R}$ (2008) The Proof of the Pudding... Benchmarking Ten of the World's Largest Food Companies' Response to Obesity and Related Health Concerns. London: JPMorgan and Insight Investment; available at http://www.insight-investment.co.uk/global/documents/ riliterature/367922/proof_of_the_pudding_pres.pdf

125. Macmullan J (2010) Left Wanting More: Food Company Policies on Marketing to Children. London: Consumers International; available at http://www.junkfoodgeneration. org/documents/Left_wanting_more.pdf

126. Wootan MG, Batada A \& Balkus O (2010) Food Marketing Report Card: An Analysis of Food and Entertainment Company Policies to Self-Regulate Food and Beverage Marketing to Children. Washington, DC: Center for Science in the Public Interest; available at http://cspinet. org/new/pdf/marketingreportcard.pdf

127. Hawkes C \& Harris J (2011) An analysis of the content of food industry pledges on marketing to children. Public Health Nutr 14, 1403-1414.

128. Swinburn B, Sacks G, Lobstein T et al. (2008) The 'Sydney Principles' for reducing the commercial promotion of foods and beverages to children. Public Health Nutr 11, 881-886.

129. Sharma LL, Teret SP \& Brownell K (2010) The food industry and self-regulation: Standards to promote success and to avoid public health failures. Am J Public Health 100, 240-246.

130. World Health Organization (2010) Set of Recommendations on the Marketing of Foods and Non-Alcoholic Beverages to Children. Geneva: WHO; available at http://whqlibdoc. who.int/publications/2010/9789241500210_eng.pdf

131. Global Reporting Initiative (2010) Reporting Framework Overview. http://www.globalreporting.org/Reporting Framework/ReportingFrameworkOverview/ (accessed November 2010).

132. Partnership Governance and Accountability Initiative (2010) The PGA Framework: Promoting Best Practice in the Management of Partnerships for Sustainable Development. http://www.pgaframework.org/index.asp (accessed November 2010).

133. Parramatta City Council (2006) Productive Partnerships Policy. Parramatta, NSW: Parramatta City Council; available at http://www.parracity.nsw.gov.au/_data/assets/ pdf_file/0011/2207/FinalProductivePartnershipsPolicy.pdf

134. Burger King (2009) BK Positive Steps: Fiscal 2009 Corporate Responsibility Report. http://www.bk.com/cms/en/us/
cms_out/digital_assets/files/pages/BK_CR_Report.pdf (accessed February 2011).

135. Cargill Inc. (2010) Corporate Responsibility Report: Growing Together. http://www.cargill.com/cs/cr-report/ overview/2010-cargill-cr-report.pdf (accessed July 2011).

136. Danone (2010) Danone 10: Danone Essentials in 2010. Economic and Social Report. http://danone10.danone. com/uk/documents (accessed July 2011).

137. General Mills (2011) Corporate Social Responsibility 2011. http://www.generalmills.com/ /media/Files/CSR/2011_ csr_final.ashx (accessed July 2011).

138. Heinz (2009) Heinz 2009 Corporate Social Responsibility Report. http://www.heinz.com/CSR2009/media/Heinz_ 2008_2009_CSR_Report.pdf (accessed July 2011).

139. Kellogg Company (2009) Corporate Responsibility Report 2009. "Bringing Our Best to You". http://www.kellogg company.com/uploadedFiles/KelloggCompany/Corporate_ Responsiblity/Kelloggs\%2009CRR_FullReport.pdf (accessed November 2010).

140. Kraft Foods (2010) Working to Build a Better World. Kraft Foods Responsibility Report. http://www.kraftfoodscompany. $\mathrm{com} /$ SiteCollectionDocuments/pdf/kraftfoods_responsibility_ report.pdf (accessed November 2010).

141. Mars Inc. (2010) Our Principles in Action. http:// www.mars.com/global/index.aspx (accessed July 2011).

142. McDonald's Corporation (2010) McDonald's 2009 Worldwide Corporate Responsibility Online Report: The Values We Bring to the Table. http://www.mcdonalds.at/presse/ maps/McDCSR.pdf (accessed February 2011).

143. McDonald's Corporation (2010) Annual Report 2010. http://www.aboutmcdonalds.com/etc/medialib/about McDonalds/investor_relations3.Par.56096.File.dat/2010\%20 Annual\%20Report\%20(print).pdf (accessed August 2011).

144. Nestlé S.A. (2009) Nestlé Creating Shared Value Report 2009. Vevey: Nestlé S.A.; available at http://www2.nestle. com/Common/NestleDocuments/Documents/Reports/CSV\% 20reports/Global\%20report\%202009/Global_report_2009_ GB.pdf

145. PepsiCo (2009) Performance With Purpose: Investing in Sustainable Growth. PepsiCo Corporate Citizenship Report Overview 2009. http://www.pepsico.com/Down load/PepsiCo_2009_Sustainability_Report_overview.pdf (accessed November 2010).

146. The Coca-Cola Company (2010) Live Positively. Our Commitment to Making a Positive Difference in the World. 2008-2009 Sustainability Review. http://www. thecoca-colacompany.com/citizenship/pdf/2008-2009_ sustainability_review.pdf (accessed November 2010).

147. The Hershey Company (2009) Corporate Social Responsibility Report 2009. http://www.thehersheycompany. com/assets/pdfs/hersheycompany/Hershey2009CSRReport. pdf (accessed July 2011).

148. Unilever (2009) Sustainable Development Overview 2009: Creating a Better Future Every Day. http://www. unilever.com/images/sd_UnileverSDReport170310_amended_ tcm13-212972.pdf (accessed November 2010).

149. Yum! Brands (2008) Serving the World. http://www.yum. com/responsibility/pdf/yum08csrrpt.pdf (accessed February 2011). 